\section{OPEN ACCESS}

Edited by:

Dr. Amanullah,

University of Agriculture, Peshawar,

Pakistan

Reviewed by:

Elizabeth Pilon-Smits,

Colorado State University, USA

Stefano Cesco,

Free University of Bozen-Bolzano, Italy

*Correspondence:

Fahim Nawaz

fahim5382@gmail.com

fahim.nawaz@iub.edu.pk

Specialty section: This article was submitted to

Plant Nutrition,

a section of the journal

Frontiers in Plant Science

Received: 23 August 2016 Accepted: 08 September 2016

Published: 27 September 2016

Citation:

Nawaz F, Naeem M, Ashraf MY, Tahir MN, Zulfiqar B, Salahuddin M,

Shabbir RN and Aslam M (2016)

Selenium Supplementation Affects

Physiological and Biochemical

Processes to Improve Fodder Yield and Quality of Maize (Zea mays L.)

under Water Deficit Conditions.

Front. Plant Sci. 7:1438.

doi: 10.3389/fpls.2016.01438

\title{
Selenium Supplementation Affects Physiological and Biochemical Processes to Improve Fodder Yield and Quality of Maize (Zea mays L.) under Water Deficit Conditions
}

\section{Fahim Nawaz ${ }^{1,2 *}$, Muhammad Naeem ${ }^{2}$, Muhammad Y. Ashraf ${ }^{4}$, Muhammad N. Tahir ${ }^{3}$, Bilal Zulfiqar', Muhammad Salahuddin ${ }^{2}$, Rana N. Shabbir ${ }^{5}$ and Muhammad Aslam²}

${ }^{1}$ Department of Agronomy, Muhammad Nawaz Sharif University of Agriculture, Multan, Pakistan, ${ }^{2}$ Department of Agronomy, UCA and ES, The Islamia University of Bahawalpur, Bahawalpur, Pakistan, ${ }^{3}$ University College of Veterinary and Animal Sciences, The Islamia University of Bahawalpur, Bahawalpur, Pakistan, ${ }^{4}$ Nuclear Institute for Agriculture and Biology, Faisalabad, Pakistan, ${ }^{5}$ Department of Agronomy, Agriculture College, Bahauddin Zakariya University, Multan, Pakistan

Climate change is one of the most complex challenges that pose serious threats to livelihoods of poor people who rely heavily on agriculture and livestock particularly in climate-sensitive developing countries of the world. The negative effects of water scarcity, due to climate change, are not limited to productivity food crops but have far-reaching consequences on livestock feed production systems. Selenium (Se) is considered essential for animal health and has also been reported to counteract various abiotic stresses in plants, however, understanding of Se regulated mechanisms for improving nutritional status of fodder crops remains elusive. We report the effects of exogenous selenium supply on physiological and biochemical processes that may influence green fodder yield and quality of maize (Zea mays L.) under drought stress conditions. The plants were grown in lysimeter tanks under natural conditions and were subjected to normal (100\% field capacity) and water stress (60\% field capacity) conditions. Foliar spray of Se was carried out before the start of tasseling stage (65 days after sowing) and was repeated after 1 week, whereas, water spray was used as a control. Drought stress markedly reduced the water status, pigments and green fodder yield and resulted in low forage quality in water stressed maize plants. Nevertheless, exogenous Se application at $40 \mathrm{mg} \mathrm{L}^{-1}$ resulted in less negative leaf water potential $(41 \%)$ and enhanced relative water contents (30\%), total chlorophyll (53\%), carotenoid contents (60\%), accumulation of total free amino acids (40\%) and activities of superoxide dismutase (53\%), catalase (30\%), peroxidase (27\%), and ascorbate peroxidase $(27 \%)$ with respect to control under water deficit conditions. Consequently, Se regulated processes improved fodder yield (15\%) and increased crude protein (47\%), fiber (10\%), nitrogen free extract (10\%) and Se content (36\%) but did not affect crude ash content in water stressed maize plants. We propose that Se foliar spray $\left(40 \mathrm{mg} \mathrm{L}^{-1}\right)$ is a handy, feasible and cost-effective approach to improve maize fodder yield and quality in arid and semi-arid regions of the world facing acute shortage of water. 


\section{INTRODUCTION}

Livestock is a major livelihood for poor people in developing countries fulfilling their social, economic and risk management functions. Climate change has increased the vulnerability of livestock systems, which may trigger a loss of livelihoods of poor communities in arid and semi-arid regions of the world. Increase in temperatures and changes in rainfall patterns would heighten the risks of existing vector-borne diseases accompanied by the emergence and spread of new diseases. Non-availability of water would severely hamper the livestock feed production systems in nomadic and desert regions of the world where people are solely dependent on livestock sector for their survival.

Drought stress negatively influences the nutritive value of forages by affecting sugar, crude fiber, protein, total ash contents and nitrogen free extracts (Bibi et al., 2012; Küchenmeister et al., 2013). Identification of an effective stress ameliorant for improving yield and quality of fodder crops under water deficit conditions is essential in today's changing climates. Selenium (Se) is not considered essential for plant growth but recent reports indicate its beneficial role in plants exposed to various abiotic stresses such as salinity (Abul-Soud and Abd-Elrahman, 2016), high temperature (Balal et al., 2016), chilling injury (HawrylakNowak et al., 2010; Akladious, 2012), metals accumulation (Li et al., 2016), UV-B induced oxidative damage (Yao et al., 2011) and drought stress (Nawaz et al., 2015a,b). Se mediated enhancement in plant resistance/tolerance to environmental stresses is attributed to its positive role in several physiological and biochemical mechanisms such as maintenance of water status (Djanaguiraman et al., 2005), enhancement in pigments (Malik et al., 2012), regulation of photosynthetic machinery (Balal et al., 2016), accumulation of osmoprotectants (Akbulut and Çakir, 2010) and activation of antioxidant enzymes (Hasanuzzaman et al., 2012; Ahmad et al., 2016). Moreover, it has also been reported to improve yield of food crops like wheat (Broadley et al., 2010; Nawaz et al., 2015b), barley (Ducsay et al., 2009), rice (Wang et al., 2013), and maize (Chilimba et al., 2012). However, the understanding of physiological and biochemical mechanisms that underlie the positive effects of Se in improving yield and quality of fodders under water deficit conditions remains elusive.

$\mathrm{Se}$ is an integral constituent of the glutathione peroxidase family (GSH-Px) and is considered essential for humans (Leccia et al., 1993) and animals (Hefnawy and Tórtora-Pérez, 2010) due to its antioxidant, anticancer, and antivirus properties. It stimulates growth and enhances resistance to diseases in animals, being involved in the production of antibodies and in the killing of microorganisms engulfed by macrophages (Khanal and Knight, 2010). Se deficiency in livestock is associated with reduced growth, appetite, muscular activity and reproductive fertility (Fordyce, 2013), whereas excessive Se intake (>1$5 \mathrm{mg} \mathrm{Se} \mathrm{kg}{ }^{-1}$ dry matter) may also result in hair loss, hoof deformation, lack of vitality and respiratory failure (Dhillon and Dhillon, 2003; White, 2016). Se intake by animals is directly related to the amount of Se taken up by the plants (Fordyce, 2005), which is linked to Se phytoavailability in the soil (White, 2016). Biofortication of fodder crops with Se is essential for the development of balanced mineral ration for livestock because many pastures are naturally low in Se levels (Žáková, 2014) particularly during spring season hence Se-fortified commercial feed additives are used to maintain the physiological Se levels in blood (Drahoňovský et al., 2016) for the prevention of Se deficiency related diseases like white muscle and reproductive infertility in cattle and sheep.

The information concerning the effects of exogenous Se supply on Se accumulation and nutritive value of forages under drought stress is limited. Here, we hypothesize that Se foliar spray influences physiological and biochemical processes to improve fodder yield and quality of maize under water deficit conditions.

\section{MATERIALS AND METHODS}

\section{Crop Husbandry and Experimental Layout}

The experiments were carried out in $1 \mathrm{~m}$ deep lysimeter tanks ( $3 \mathrm{~m}$ length $\times 3 \mathrm{~m} \mathrm{dia)}$ separated by a buffer zone of $15 \mathrm{~cm}$ thick-cemented wall on each side to prevent seepage losses. The lysimeters were fitted with a manually operated moveable, light transmissive rain-out shelter. Precision leveling was done before sowing to ensure even distribution of water. The soil samples arbitrarily collected from three different sites of each tank were used to determine the physiochemical characteristics of the soil according to the method of Jackson (1962) with results as follows: soil texture $=$ sandy loam; $\mathrm{pH}=7.89$; saturation percentage $=32.11 \%$; electrical conductivity $=0.97$ $\mathrm{dS} \mathrm{m}^{-1}$; soil organic matter $=0.87 \%$; available phosphorous $(\mathrm{P})=10.39 \mathrm{mg} \mathrm{kg}^{-1}$; potassium $(\mathrm{K})=68 \mathrm{mg} \mathrm{kg}^{-1}$ and nitrogen $(\mathrm{N})=347 \mathrm{mg} \mathrm{kg}^{-1}$. Total Se content in the soil was determined following the procedure described by Ramos et al. (2010) and was found to be $0.074 \mathrm{mg} \mathrm{kg}^{-1}$. Plant nutrient requirements of $\mathrm{N}$, $\mathrm{P}$, and $\mathrm{K}$ were met by the application of recommended doses of urea $\left(250 \mathrm{~kg} \mathrm{ha}^{-1}\right)$, diammonium phosphate $\left(140 \mathrm{~kg} \mathrm{ha}^{-1}\right)$ and sulfate of potash $\left(150 \mathrm{~kg} \mathrm{ha}^{-1}\right)$. All P, K, and $1 / 8$ th $\mathrm{N}$ was mixed the surface layer $(0-15 \mathrm{~cm})$ before sowing, whereas $1 / 5$ th $\mathrm{N}$ was applied at $\mathrm{V} 2$ and the remaining $\mathrm{N}$ was broadcasted in two equal splits at V12 and V14 growth stages of maize.

The seeds of indigenous maize cultivar (Zea mays $\mathrm{L}$. cv. Pak-Afghoi) were obtained from Regional Agricultural Research Institute (RARI), Bahawalpur and were disinfected with recommended doses of Topsin-M 70 WP $\left(2-2.5 \mathrm{~g} \mathrm{~kg}^{-1}\right.$ seed) and Imidacloprid $\left(4 \mathrm{~g} \mathrm{~kg}^{-1}\right.$ seed) prior to sowing. The seeds were hand drilled in rows of $0.80 \mathrm{~m}$ length keeping $\mathrm{P} \times \mathrm{P}$ and $\mathrm{R} \times \mathrm{R}$ distance of 0.20 and $0.70 \mathrm{~m}$, respectively when soil was at field capacity (FC) condition. The weeds were uprooted manually whenever found necessary. The experiment was laid out in a $2 \times 2$ factorial scheme and experimental setup consisted of four treatments: normal irrigations with water spray $(\mathrm{N})$, Se foliar spray under normal conditions (Se), drought stress with water spray (D) and Se foliar under drought stress conditions (D+Se) with three repeats. The plants were harvested 1 week after the second foliar treatment and the youngest, fully expanded fresh leaves were collected before harvesting for the determination of physiological and biochemical attributes in maize. 


\section{Drought Stress and Se Treatments}

Drought stress treatments, i.e., normal water supply (100\% FC) and water stress ( $60 \%$ FC) were allocated separately to each tank in the lysimeter. The normal plants received approximately $790 \mathrm{~mm}$ tap water (an irrigation of $75-80 \mathrm{~mm}$ per week), whereas water stressed plants received approximately $500 \mathrm{~mm}$ irrigation water (about 48-50 mm irrigation applied per week) till harvesting. A water meter fixed at the water supply equipment was used to estimate the quantity of applied irrigations.

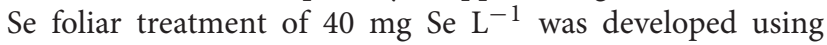
sodium selenate $\left(\mathrm{Na}_{2} \mathrm{SeO}_{4} ; \mathrm{MW}=188.95\right.$; purity $\geq 98.0 \%$; Sigma-Aldrich, St. Louis, MO, USA) and was later verified analytically using atomic absorption spectrometry technique (Krishnaiah et al., 2003). Se foliar spray, containing $0.1 \%$ Tween20, was carried out before the onset of tasseling stage (65 days after sowing) and was repeated after 1 week. Water spray, containing the same amount of Tween-20 (0.1\%), was used as a control. The spraying was performed with a compression layer of $1 \mathrm{~L}$ capacity and was carried out early in the morning (between 06:00 and 08:00 a.m.). The plants were harvested at late vegetative stage (V16-17) to determine green fodder yield (only first cutting yield was taken).

\section{Measurement of Leaf Water Status}

The fully expanded youngest, fresh leaf collected for each treatment was used for the estimation of leaf water potential $\left(\Psi_{\mathrm{w}}\right)$ using "Scholander" type pressure chamber Model 1000 (PMS, Oregon-USA). The same leaf was weighed immediately afterward to record fresh weight (FW) and then dipped in distilled water for $24 \mathrm{~h}$ at $4^{\circ} \mathrm{C}$. The leaves were then taken out, wiped with a tissue paper and the turgid weight (TW) was recorded. For dry weight (DW) determination, the samples were kept in an oven at $65^{\circ} \mathrm{C}$ for $72 \mathrm{~h}$. Leaf relative water contents (RWCs) were calculated according to the following formula reported by Mayak et al. (2004).

$$
\mathrm{RWC}=[(\mathrm{FW}-\mathrm{DW}) /(\mathrm{TW}-\mathrm{DW})] \times 100 .
$$

The excised leaf water loss (ELWL) was also estimated on youngest leaves, which were excised and weighed immediately to record FW. The leaves were then incubated for $6 \mathrm{~h}$ at $28^{\circ} \mathrm{C}$ and $50 \%$ relative humidity to record incubation weight (IW) and later put in an oven at $65^{\circ} \mathrm{C}$ for $72 \mathrm{~h}$ to estimate DW. The following formula proposed by Clarke and McCaig (1982) was used to calculate ELWL.

$$
\mathrm{ELWL}=(\mathrm{FW}-\mathrm{IW}) /(\mathrm{FW}-\mathrm{DW}) \times 100 .
$$

For the determination of excised leaf water retention (ELWR), the youngest leaves collected for each treatment were weighed to record FW, kept at room temperature $\left(25^{\circ} \mathrm{C}\right)$ for $6 \mathrm{~h}$ and reweighed (WL). ELWR was calculated using the following formula suggested by Lonbani and Arzani (2011).

$$
\mathrm{ELWR}=(\mathrm{FW}-\mathrm{WL}) / \mathrm{FW} \times 100 .
$$

\section{Estimation of Pigments}

Fresh leaf material $(1.0 \mathrm{~g})$ collected for each treatment was chopped into $0.5 \mathrm{~cm}$ segments and later extracted in
$10 \mathrm{~mL}$ acetone $(80 \%)$ at $4^{\circ} \mathrm{C}$ over-night for the estimation of chlorophyll $(\mathrm{Chl})$ and carotenoid (Car) contents according to the methods of Arnon (1949) and Davies (1976). Following formulae were used to calculate $\mathrm{Chl}_{\mathrm{a}}, \mathrm{Chl}_{\mathrm{b}}$, total $\mathrm{Chl}$ and CAR contents after measuring the absorbance of supernatant on a spectrophotometer (Hitachi, U-2800) at 645, 652, 663, and $480 \mathrm{~nm}$.

$$
\begin{aligned}
& \mathrm{Chl}_{\mathrm{a}}\left(\mathrm{mg} \mathrm{g}^{-1} \mathrm{FW}\right)=[12.7(\mathrm{OD} 663)-2.69(\mathrm{OD} 645)] \\
& \mathrm{x} \mathrm{V} / 1000 \times \mathrm{W} \\
& \mathrm{Chl}_{\mathrm{b}}\left(\mathrm{mg} \mathrm{g}^{-1} \mathrm{FW}\right)=[22.9(\mathrm{OD} 645)-4.68(\mathrm{OD} 663)] \\
& \mathrm{x} \mathrm{V} / 1000 \mathrm{xW} \\
& \mathrm{Chl}_{\mathrm{t}}\left(\mathrm{mg} \mathrm{g}^{-1} \mathrm{FW}\right)=[20.2(\mathrm{OD} 645)+8.02(\mathrm{OD} 663)] \\
& \mathrm{x} V / 100 \times \mathrm{W} \\
& \operatorname{CAR}\left(\mu \mathrm{gg}^{-1} \mathrm{FW}\right)=\mathrm{A}^{\mathrm{car}} / \mathrm{E}_{\mathrm{mx}}{ }^{100} .
\end{aligned}
$$

Where $\mathrm{V}$ is the volume of sample extract and $\mathrm{W}$ is the weight of the sample and $A^{\text {car }}=(\mathrm{OD} 480)+0.114$ (OD663) -0.638 (OD645); $\mathrm{E}_{\max }^{100} \mathrm{~cm}=2500$.

\section{Detection of Total Free Amino Acids and Antioxidant Enzymes Activities}

Fresh leaf material $(1.0 \mathrm{~g})$ was used to estimate total free amino acids (TFA) following the reports of Hamilton and Van Slyke (1943).

The activities of peroxidase (POX), superoxide dismutase (SOD), catalase (CAT), and ascorbate peroxidase (APX) were determined spectrophotometrically. Fresh leaf material (1 g) was homogenized in $50 \mathrm{mM}$ phosphate buffer with $7.0 \mathrm{pH}$ and $1 \mathrm{mM}$ dithiothreitol (DTT) as described by Dixit et al. (2001). The procedure published by Zhang et al. (2012) was used to determine CAT and POX activities, whereas APX and SOD activities were measured according to the methods of Cakmak (1994) and Giannopolitis and Ries (1997), respectively.

\section{Determination of Shoot Se Content and Fodder Quality Attributes}

The dried ground material ( $1 \mathrm{~g}$ ) of above ground plant tissues (shoot and leaves) was homogenized to estimate Se accumulation in shoot using ICP-OES (Optima 2100-DV Perkin-Elmer) according to the method published in our early report (Nawaz et al., 2015b).

For fodder quality attributes, dry feeds were sampled once during each period, dried under shade for 4-5 days and milled through a $2 \mathrm{~mm}$ screen in a hammer mill POLYMIX $^{(R)}$ PXMFC Kinematica AG Germany). Sub-samples of all feeds were analyzed for DM (Association of Official Analytical Chemists (AOAC, 1984; method 7.003), ash $\left(525^{\circ} \mathrm{C}\right.$ for $6 \mathrm{~h}$; AOAC, 1984; method 923.03), CP (AOAC, 1984; method 7.015) and crude fiber (Weende method). The nitrogen free extract was calculated as $\% \mathrm{NFE}=100-(\%$ crude protein $+\%$ crude fat $+\%$ crude fiber $+\%$ moisture $+\%$ ash $)$. 


\section{Statistical Analysis}

Analysis of variance (ANOVA) technique was used to statistically analyze data on STATISTIX Computer Program (Version 8.1). The significant differences among treatments' means were compared using post hoc Tukey test at $P \leq 0.05$.

\section{RESULTS}

\section{Leaf Water Status}

Drought stress $(60 \%$ FC) markedly $(P<0.05)$ reduced the leaf water status of maize plants (Table 1). The plants supplemented with Se exhibited non-significant difference for $\Psi_{\mathrm{w}}$ under normal conditions ( $100 \%$ FC), however, Se foliar spray markedly enhanced $\Psi_{\mathrm{w}}$ by $41 \%$ with respect to no Se supply (control) under drought stress conditions (Figure 1A). Similar trend was noted for leaf RWC and ELWL as Se supplementation increased RWC by $30 \%$ (Figure 1B), whereas, it reduced ELWL by $44 \%$ (Figure 1C) in water stressed maize plants. Foliar Se spray also increased ELWR by $8 \%$ (Figure 1D) however, the interactive effects of $\mathrm{Se} \times \mathrm{D}$ were found to be non-significant for this variable (Table 1).

\section{Pigments}

The exposure to drought stress significantly $(P<0.05)$ reduced leaf photosynthetic pigments such as $\mathrm{Chl}_{\mathrm{a}}, \mathrm{Chl}_{\mathrm{b}}, \mathrm{Chl}_{\mathrm{t}}$ and $\mathrm{CAR}$ contents by $75,60,71$, and $84 \%$, respectively compared to the control (100\% FC). However, maize plants supplemented with Se exhibited an increase of 54, 86, 53, and 60\% in leaf $\mathrm{Chl}_{\mathrm{a}}$ (Figure 2A), $\mathrm{Chl}_{\mathrm{b}}$ (Figure 2B), $\mathrm{Chl}_{\mathrm{t}}$ (Figure 2C) and CAR contents (Figure 2D), respectively than those sprayed with water (control) under drought stress conditions.

\section{TFA and Antioxidant Enzymes}

The normal plants supplemented with Se at 100\% FC did not exhibit significant difference $(P>0.05)$ for the accumulation of TFA (Table 2), however, a marked increase (40\%) in TFA content was noted by foliar Se spray in water stressed $(60 \%$ FC) maize plants (Figure 3A). Similarly, exogenous Se supply did not significantly influence the activities of antioxidant enzymes under normal conditions. However, at 60\% FC, foliar Se supplementation increased the activities of SOD, CAT, POX, and APX by 53\% (Figure 3B), 30\% (Figure 3C), 27\% (Figure 3D), and $27 \%$ (Figure 3E), respectively with respect to control (water spray).

\section{Fodder Quality Attributes}

A marked reduction of 47, 16, 23, 38, and 15\% was recorded in $\mathrm{CP}, \mathrm{CF}, \mathrm{CA}, \mathrm{MC}$, and $\mathrm{NFE}$, respectively under water deficit conditions. However, foliar Se spray significantly enhanced the quality attributes of fodder maize and increased CP, CF, MC, and NFE by 47\% (Figure 4A), 10\% (Figure 4B), 15\% (Figure 4D), and $10 \%$ (Figure 4E), respectively but did not significantly affect CA contents (Figure 4C). The interactive effects $(\mathrm{Se} \times \mathrm{D})$ were also found to be non-significant for fodder quality attributes (Table 3).

\section{GFY and Shoot Se Content}

Drought exposure $(60 \%$ FC) significantly reduced the GFY of maize plants by $23 \%$ and markedly influenced the shoot Se content compared to the control (100\% FC). Foliar Se supplementation was found to be effective in increasing GFY (15\%) in water stressed maize plants only and did not significantly influence it under normal conditions (Figure 5A). Moreover, exogenous Se supply resulted in 36\% higher Se contents in water stressed than normal maize plants (Figure 5B).

\section{DISCUSSION}

Maintenance of turgor through accumulation of solutes is one of the key defense mechanisms in plants to withstand the negative effects of environmental stresses particularly drought stress (Shabbir et al., 2016). The exposure to limited water supply (60\% FC) markedly reduced the water status of maize plants and resulted in more negative $\Psi_{\mathrm{w}}$ because the maintenance of favorable water relations is considered prime defense strategy of plants to tolerate drought stress (Kaldenhoff et al., 2008; Hussain et al., 2016). It was noticed that Se foliar spray resulted in less negative leaf $\Psi_{\mathrm{w}}$ (Table 1), which is in agreement with the reports on potato (Germ et al., 2007), wheat (Nawaz et al., 2015a) and maize (Qiang-yun et al., 2008; Sajedi et al., 2011). The Se mediated increase in $\Psi_{\mathrm{w}}$ might be due to its positive role in osmotic balance and ion homeostasis to increase water uptake (Kuznetsov et al., 2003) and reduce transpiration under drought stress conditions (Yao et al., 2009). The results of present study suggest that Se regulates the net accumulation of osmolytes or simple passive concentration of solutes to maintain water status in water stressed plants (Nawaz et al., 2015b). The reduction in ELWL by Se supplementation might be attributed to less negative $\Psi_{\mathrm{w}}$ resulting in low residual transpiration (Balal et al., 2016) in under water deficit conditions. The exposure to drought stress disturbs the osmotic balance of plants that reduces turgidity

TABLE 1 | Summary of the ANOVA for leaf water potential (WP), relative water contents (RWCs), excised leaf water loss (ELWL) and excised leaf water retention (ELWR), chlorophyll a $\left(\mathrm{Chl}_{\mathrm{a}}\right)$, chlorophyll b $\left(\mathrm{Chl}_{\mathrm{b}}\right)$, total chlorophyll $\left(\mathrm{Chl} \mathrm{l}_{\mathrm{t}}\right)$, and carotenoid (CAR) contents in Zea mays.

\begin{tabular}{|c|c|c|c|c|c|c|c|c|}
\hline sov & $\Psi_{w}(-M P a)$ & RWC (\%) & ELWL (\%) & ELWR (\%) & $\mathrm{Chl}_{\mathrm{a}}\left(\mathrm{mg} \mathrm{g}^{-1} \mathrm{FW}\right)$ & $\mathrm{Chl}_{\mathrm{b}}\left(\mathrm{mg} \mathrm{g}^{-1} \mathrm{FW}\right)$ & $\mathrm{Chl}_{\mathrm{t}}\left(\mathrm{mg} \mathrm{g}^{-1} \mathrm{FW}\right)$ & CAR $\left(\mu \mathrm{g} \mathrm{g}^{-1} \mathrm{FW}\right)$ \\
\hline Selenium (Se) & $* *$ & $* *$ & $*$ & $*$ & $* * *$ & $* *$ & $* * *$ & $* * *$ \\
\hline Drought (D) & $* * *$ & $* * *$ & $* * *$ & $* * *$ & $* * *$ & $* * *$ & $* * *$ & $* * *$ \\
\hline $\mathrm{Se} \times \mathrm{D}$ & $*$ & $*$ & $* *$ & NS & NS & NS & NS & $* *$ \\
\hline CV & 10.03 & 5.04 & 11.44 & 3.59 & 5.27 & 12.34 & 4.21 & 2.65 \\
\hline
\end{tabular}

Significant differences are indicated by an asterisk $\left({ }^{*}\right)$; ${ }^{*} P \leq 0.05$, ${ }^{* *} P \leq 0.01,{ }^{* * *} P \leq 0.001$; NS, non-significant; SOV, source of variation; CV, coefficient of variation. 

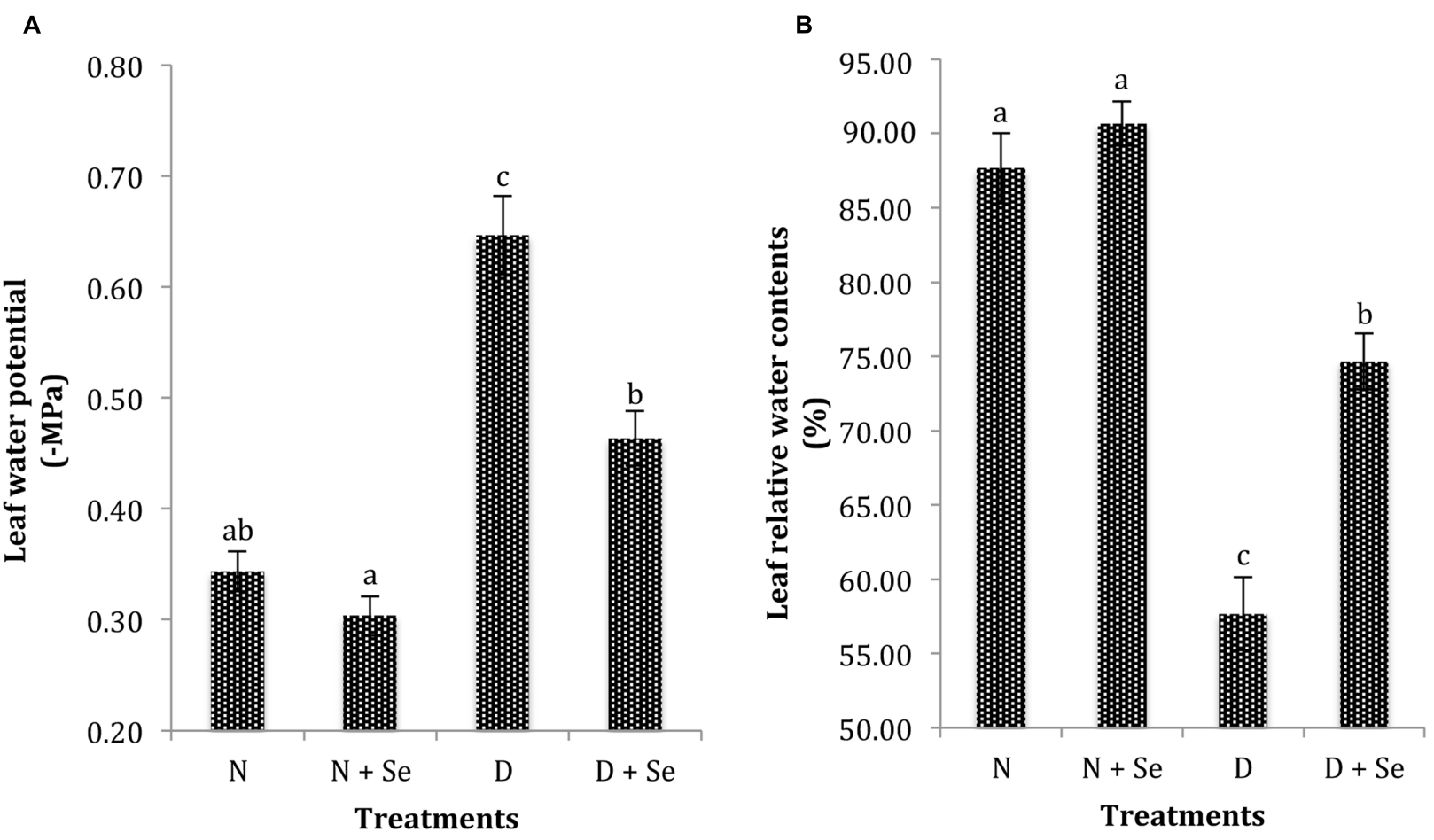

C

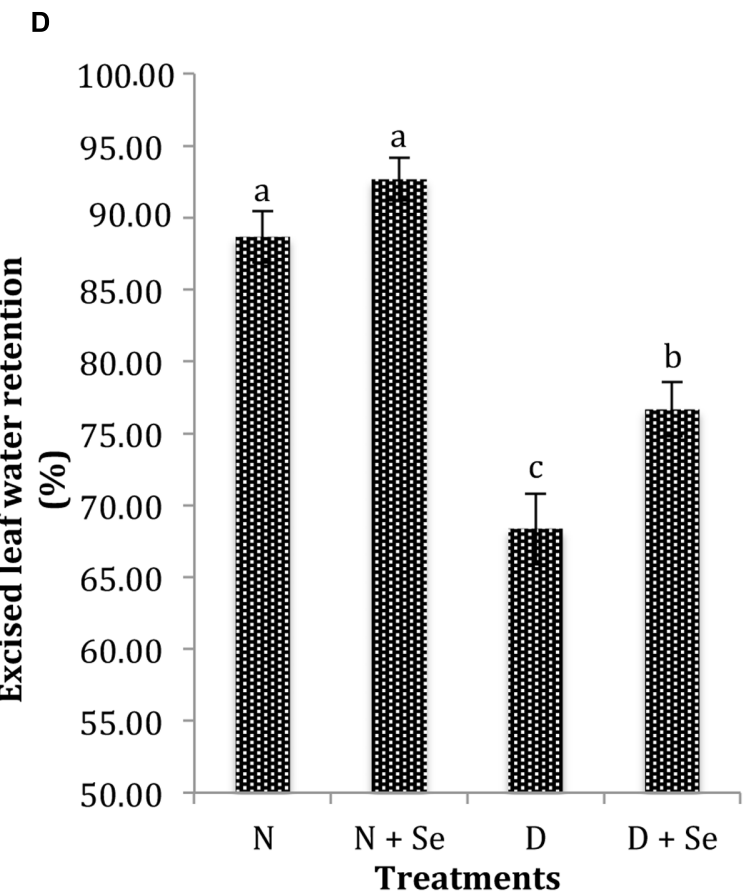

FIGURE 1 | Effect of Se foliar spray on leaf water status, (A) water potential $\left(\Psi_{w}\right)(B)$ relative water contents (RWC) (C) excised leaf water loss (ELWL) (D) excised leaf water retention (ELWR) of Zea mays exposed to drought stress. Values represent mean \pm SE. Different letters represent significant differences at $P \leq 0.05$, after applying post hoc Tukey's test.

and cell elongation (Shabbir et al., 2016). Previous reports have demonstrated that decrease in $\Psi_{\mathrm{w}}$ causes a parallel reduction in RWC (Živčák et al., 2009; Raza et al., 2012; Nawaz et al., 2015a). We found that Se supplementation significantly increased the RWC of only water stressed maize plants (Figure 1B). The positive effects of Se supply on leaf RWC were also described by Wang (2011) and Hajiboland et al. (2014) in water stressed Triticum aestivum and Trifolium repens plants, respectively. 


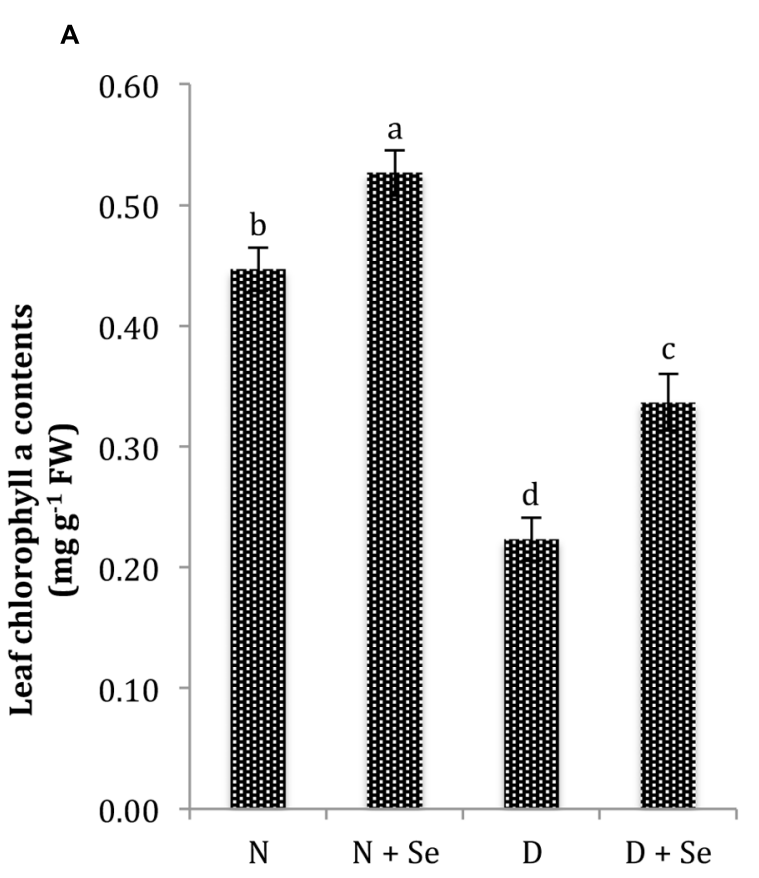

Treatments

C

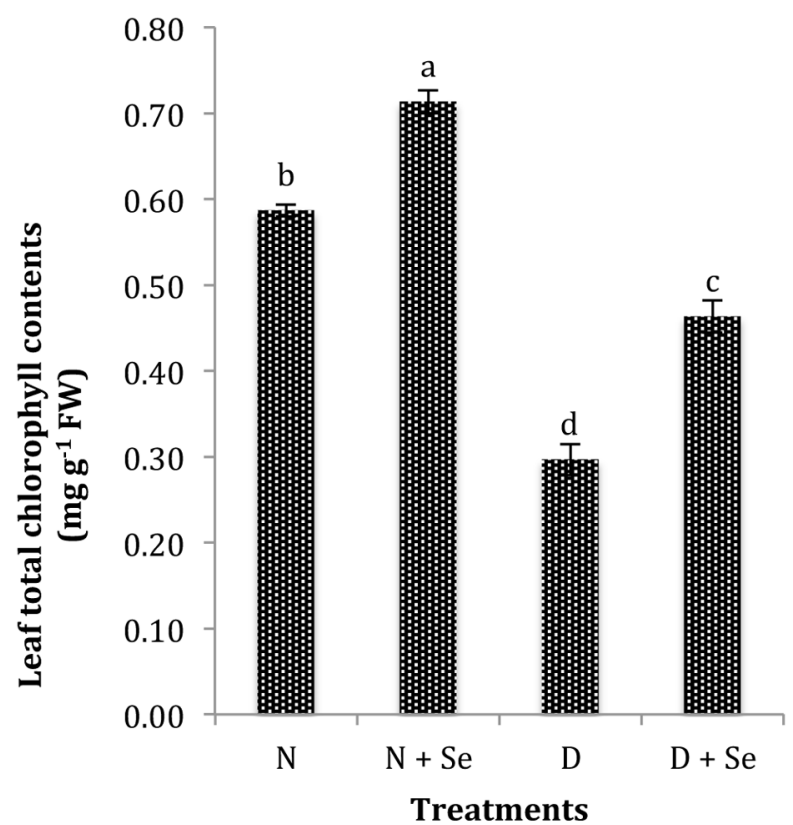

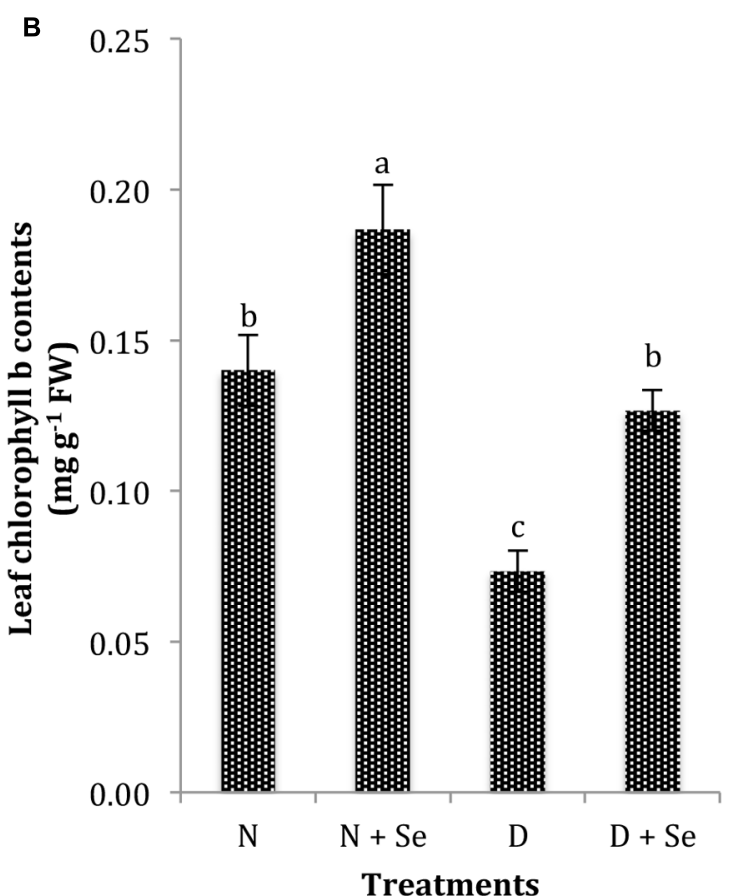

D

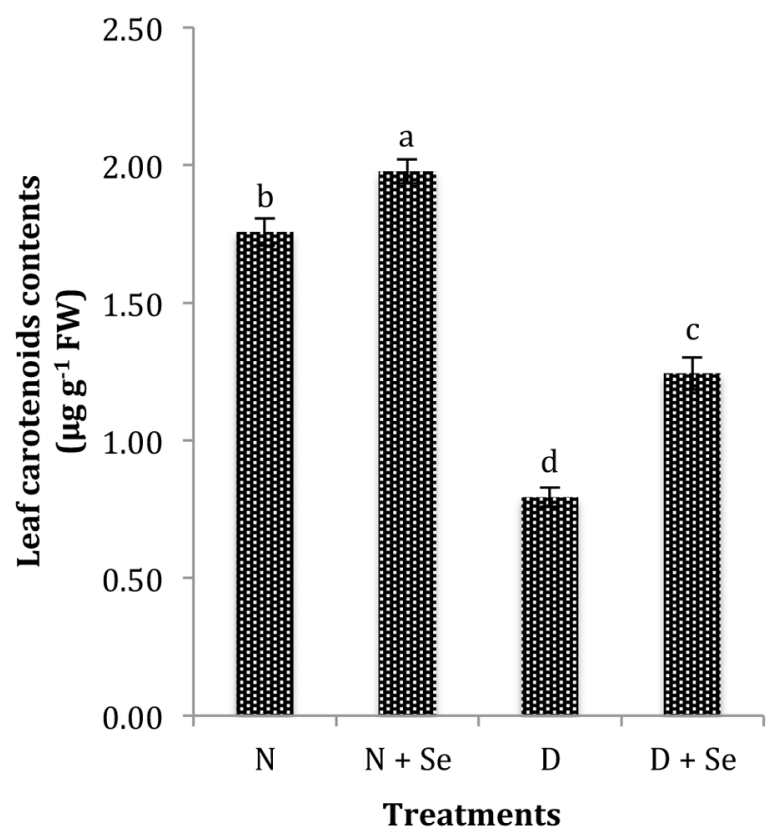

FIGURE 2 | Effect of Se foliar spray on leaf photosynthetic pigments, (A) chlorophyll a (Chl $)$ (B) chlorophyll b (Chl $\mathrm{b}_{\mathrm{b}}$ ) (C) total chlorophyll (Chl $\mathrm{t}$ ) (D) carotenoid contents (CAR) of Zea mays exposed to drought stress. Values represent mean \pm SE. Different letters represent significant differences at $P \leq 0.05$, after applying post hoc Tukey's test.

Contrary to our results, Habibi (2013) recorded the highest RWC in Se supplemented Hordeum vulgare plants grown under normal conditions. The stimulating effect of exogenous Se supply may be due to increase in membrane integrity (Nawaz et al., 2015a) or decrease in photo-oxidation (Seppänen et al., 2003).
Exogenous Se supply minimizes the damage to the chloroplasts and helps to maintain photosynthetic pigments under environmental stress conditions (Zahedi et al., 2013; Khan et al., 2015; Abd-Allah et al., 2016; Balal et al., 2016). In present study, we noticed similar results in maize plants foliar applied 
TABLE 2 | Summary of the ANOVA for total free amino acids (TFA), superoxidase dismutase (SOD), catalase (CAT), peroxidase (POX), ascorbate peroxidase (APX), green fodder yield (GFY), and shoot Se content in Zea mays.

\begin{tabular}{|c|c|c|c|c|c|c|c|}
\hline sov & $\begin{array}{c}\text { TFA ( } \mu \mathrm{mol} \\
\left.\mathrm{g}^{-1} \mathrm{FW}\right)\end{array}$ & $\begin{array}{c}\text { SOD (Units } \\
\min ^{-1} \mathrm{~g}^{-1} \mathrm{FW} \text { ) }\end{array}$ & $\begin{array}{c}\text { CAT (Units } \min ^{-1} \\
\mathrm{~g}^{-1} \mathrm{FW} \text { ) }\end{array}$ & $\begin{array}{c}\text { POX (Units } \min ^{-1} \\
\mathrm{~g}^{-1} \mathrm{FW} \text { ) }\end{array}$ & $\begin{array}{c}\text { APX (ABA digested } \\
\left.\mathrm{g}^{-1} \mathrm{FW} \mathrm{h}^{-1}\right)\end{array}$ & GFY (t ha-1) & $\begin{array}{c}\text { Se contents ( } \mu \mathrm{g} \\
\left.\mathrm{kg}^{-1} \mathrm{DW}\right)\end{array}$ \\
\hline Selenium (Se) & $*$ & $* * *$ & $* * *$ & $* * *$ & $* * *$ & $* *$ & $* * *$ \\
\hline Drought (D) & $* * *$ & $* * *$ & $* * *$ & $* * *$ & $* * *$ & $* * *$ & NS \\
\hline Se $\times D$ & $*$ & $* * *$ & $* *$ & $* * *$ & $* * *$ & $*$ & NS \\
\hline CV & 11.91 & 4.08 & 5.01 & 5.23 & 5.15 & 2.60 & 11.70 \\
\hline
\end{tabular}

Significant differences are indicated by an asterisk ( $\left.{ }^{*}\right) ;{ }^{*} P \leq 0.05,{ }^{*} P \leq 0.01,{ }^{* * *} P \leq 0.001$; NS, non-significant; SOV, source of variation; CV, coefficient of variation.

with Se under drought stress (60\% FC) conditions. Reduction in photosynthetic pigments in water stressed maize plants could have been due to chlorophyll disintegration by over production of ROS (Khayatnezhad et al., 2011). Exogenous Se supplementation influences the activities of antioxidant enzymes such as CAT, POX, APX, and SOD (also noted in present study), which help to prevent lipid peroxidation for efficient photosynthetic activity under various abiotic stresses (Habibi, 2013; Balal et al., 2016). Djanaguiraman et al. (2005) found that low Se concentrations alter chlorophyll biosynthetic pathway to increase pigments in plants. As described by Chu et al. (2010) in wheat seedlings subjected to cold stress, we found that foliar Se spray significantly enhanced the CAR contents (Figure 2D) in Zea mays exposed to water deficit conditions. Reports on Lycium chinense (Dong et al., 2013) and Sorghum bicolor (Abbas, 2012) suggest that Se supplementation enhances photosynthetic pigments at low doses but causes a marked reduction at high doses due to negative effect on the production of porphobilinogen synthetase (Padmaja et al., 1995) or replacement of sulfur (S) atoms by Se in S-containing amino acids, cysteine and methionine (Terry et al., 2000). However, Hawrylak-Nowak (2009) observed non-significant effect of Se supplementation on CAR contents of cucumber plants. Se mediated increase in CAR pigments further supports the theory that CAR pigments are involved in scavenging of free radicals and maintenance of membrane integrity (Peng and Zhou, 2009).

Foliar Se spray significantly increased the accumulation of osmotically active molecules like TFA (Figure 3A), which helped drought stressed maize plants to maintain water status. It can be inferred from the results that Se stimulates amylase activity to increase starch decomposition under water deficit conditions. Early reports on Glycine max, Solanum tuberosum, Brassica napus, and Zizyphus jujube (Djanaguiraman et al., 2004; Turakainen et al., 2004; Hajiboland and Keivanfar, 2012; Zhao et al., 2013) are concordant with our results suggesting that exposure to environmental stresses like drought results in the breakdown of structural proteins to promote biosynthesis and accumulation of amino acids (Hsu et al., 2003), which actively take part in osmotic adjustment under drought stress conditions (Good and Zaplachinski, 1994). Djanaguiraman et al. (2004) were of the view that Se supplementation disturbs the amino acid metabolism, which increases soluble protein content and nitrate reductase activity in water stressed plants. The increased activities of antioxidant enzymes indicate excessive ROS production under drought stress conditions (Cartes et al., 2010; Hasanuzzaman and Fujita, 2011). These enzymes serve as highly efficient machinery for detoxification of $\mathrm{O}_{2}{ }^{-}$and $\mathrm{H}_{2} \mathrm{O}_{2}$ and help to prevent the formation of highly toxic $\mathrm{HO}^{-}$(Mittler et al., 2004). A marked increase in SOD, CAT, POX, and APX production by Se supplementation provides further evidence that Se regulates the spontaneous dismutation of $\mathrm{O}_{2}{ }^{-}$into $\mathrm{H}_{2} \mathrm{O}_{2}$ (Hartikainen et al., 2000; Cartes et al., 2010) or may be directly involved in quenching of $\mathrm{O}_{2}{ }^{-}$and $\mathrm{OH}^{-}$in cells (Xu et al., 2007). Previous studies in wheat (Yao et al., 2009; Nawaz et al., 2015a), barley (Habibi, 2013), tomato (Balal et al., 2016), and rice (Xu and $\mathrm{Hu}$, 2004) also reported an increase in the activity of antioxidant machinery in Se supplemented plants exposed to a wide range of abiotic stresses. It is crucial to maintain balance between SOD and other ROS scavenging enzymes to determine the steady-state level of $\mathrm{O}_{2}{ }^{-}$and $\mathrm{H}_{2} \mathrm{O}_{2}$ in cells (Mittler et al., 2004) hence the exogenous application of appropriate doses of Se is involved in the reactivation of ROS quenchers like SOD, POX, and GSH-PX to reduce $\mathrm{H}_{2} \mathrm{O}_{2}$ levels in plants exposed to stressful environments (Filek et al., 2009; Kumar et al., 2012). Earlier, Sajedi et al. (2011) reported increased antioxidant activity in Se supplemented maize plants and suggested that single but not the combined use of Se or micronutrients mitigates drought stress in plants. However, the excessive Se doses not only reduce the POX activities (Nowak et al., 2004) but also cause damage to plant tissues (Marschner, 1995; Nawaz et al., 2013).

Drought induced reduction in maize fodder yield and quality corresponds to the reports in sorghum-sudan grass (Bibi et al., 2012) and ryegrass (Abraha et al., 2015). Positive effects of Se on yield of food crops are well-documented (Ducsay et al., 2009; Chilimba et al., 2012; Wang et al., 2013; Nawaz et al., 2015b), however, reports regarding role of Se in improving forages yield are scanty. Availability, of high soil moisture content is one of most critical factors influencing the yield of forages in water-limited environment (Staniak and Kocoń, 2015). Presumably, Se mediated increase in maize fodder yield is related to the maintenance of turgor and enhancement in photosynthetic pigments that helped plants to produce more biomass under water deficit conditions. Foliar Se application significantly increased the fodder quality attributes such as $\mathrm{CP}$, $\mathrm{CF}$, and NFE which might be attributed to improved water status and increased activity of antioxidant machinery that would have stimulated uptake of minerals and translocation of assimilates to shoot which enhanced fodder quality. Our results are concordant with the reports of Pii et al. (2015) who were of the view that physiological processes and biochemical 

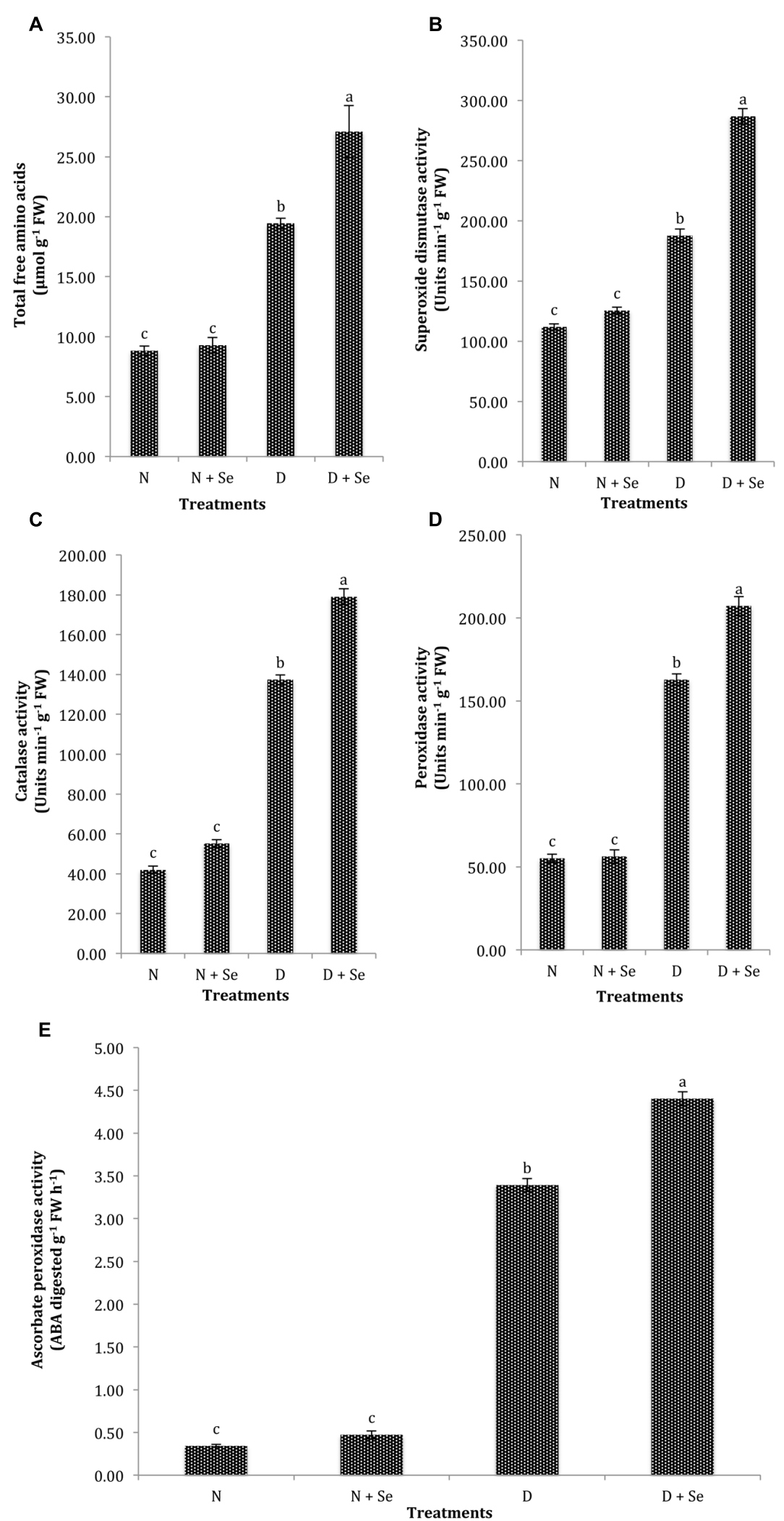

FIGURE 3 | Effect of Se foliar spray on osmoprotectants accumulation and activities of antioxidant enzymes, (A) total free amino acids (TFA) (B) superoxide dismutase (SOD) (C) catalase (CAT) (D) peroxidase (POX) (E) ascorbate peroxidase (APX) of Zea mays exposed to drought stress. Values represent mean $\pm \mathrm{SE}$. Different letters represent significant differences at $P \leq 0.05$, after applying post hoc Tukey's test. 
A

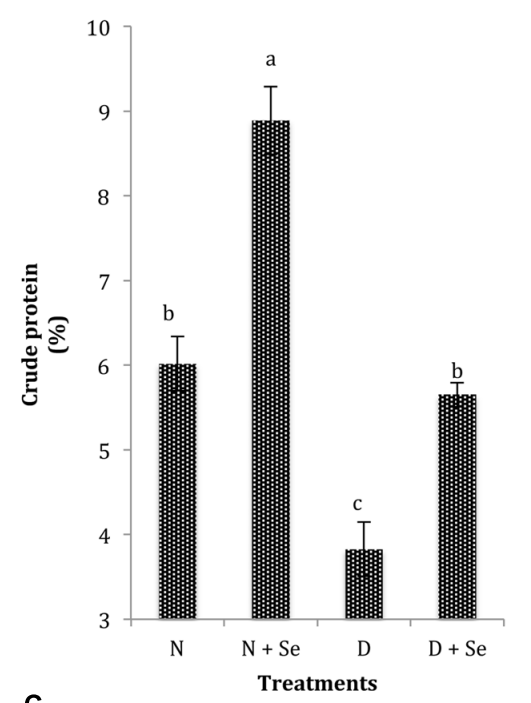

C

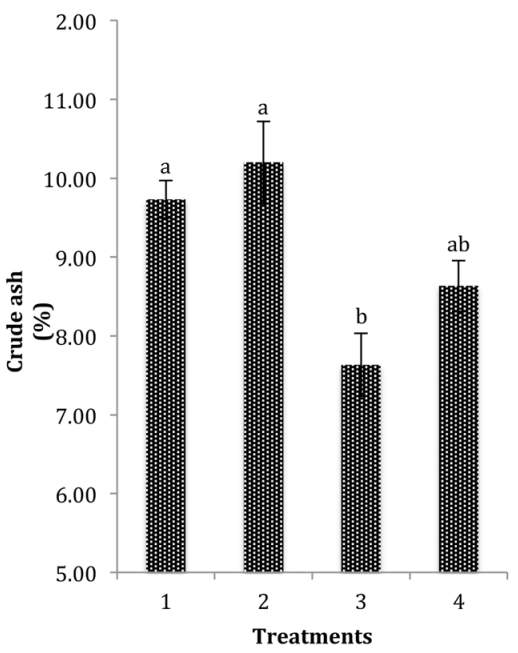

E

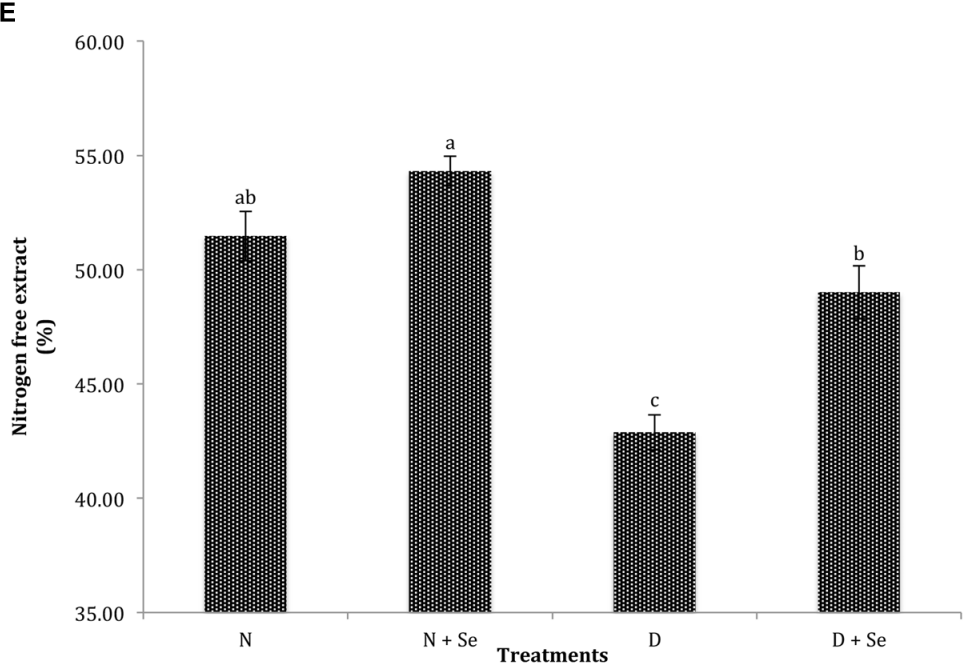

B

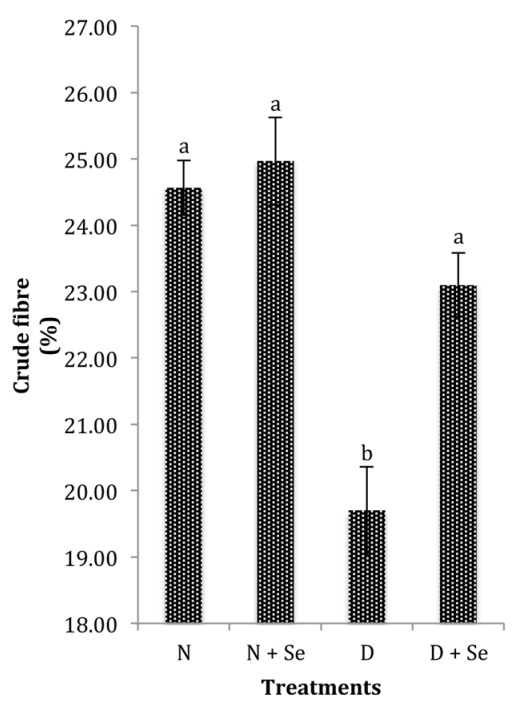

D

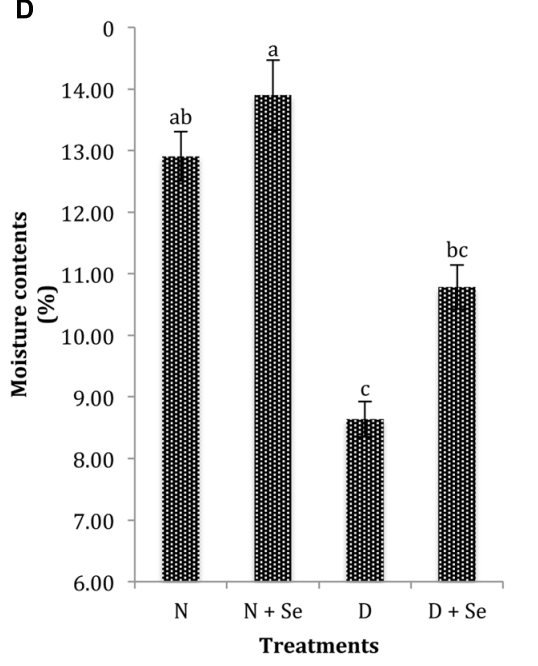

FIGURE 4 | Effect of Se foliar spray on fodder quality, (A) crude protein (CP) (B) crude fiber (CF) (C) crude ash (CA) (D) moisture contents (MC) (E) nitrogen free extract (NFE) of Zea mays exposed to drought stress. Values represent mean \pm SE. Different letters represent significant differences at $P \leq 0.05$, after applying post hoc Tukey's test. 
activities including enzyme activation control the elemental uptake that defines the nutritional status of plants. However, interactions between Se and other elements are also wellreported in literature for example; Yao et al. (2013) documented that exogenous Se supply significantly enhanced the uptake of $\mathrm{Fe}, \mathrm{K}$ and $\mathrm{Zn}$ in wheat, whereas, Pazurkiewicz-Kocot et al. (2008) noticed that Se supplementation increased the $\mathrm{K}$ contents in maize grains but inhibited the accumulation of $\mathrm{Ca}$ and $\mathrm{Mg}$ in roots. Recently, Drahoňovský et al. (2016) observed marked increase in Ca contents of Se supplemented Chaerophyllum temulum and Veronica chamaedrys, hence, further targeted research is necessary to investigate the relation between Se supply and nutrients uptake and its association with fodder quality attributes. Increased Se content in maize plants supports our hypothesis that foliar Se supply can be utilized as an effective strategy for the biofortification of fodder crops (Drahoňovský et al., 2016) to prepare balanced mineral ration for livestock in areas with low Se levels in pastures (Žáková, 2014). Higher Se contents in water stressed plants might be due to enhanced activities of antioxidant enzymes with respect to control (Hartikainen et al., 2000). Cartes et al. (2005) documented that a positive correlation exists between shoot Se concentration and GSH-Px activity, which might be responsible for increased shoot Se content under water deficit conditions. Our results further support the notion that soil moisture influences Se availability and accumulation, as it is
TABLE 3 | Summary of the ANOVA for crude protein (CP), crude fiber (CF), crude ash (CA), moisture contents (MC), and nitrogen free extract (NFE) in Zea mays.

\begin{tabular}{lccccc}
\hline Sov & CP (\%) & CF (\%) & CA (\%) & MC (\%) & NFE (\%) \\
\hline Selenium (Se) & $*$ & $*$ & NS & $*$ & $* *$ \\
Drought (D) & $* * *$ & $* *$ & $* *$ & $* * *$ & $* * *$ \\
Se $\times$ D & NS & NS & NS & NS & NS \\
CV & 9.96 & 4.61 & 8.07 & 6.88 & 3.69
\end{tabular}

Significant differences are indicated by an asterisk (*); $* P \leq 0.05,{ }^{*} P \leq 0.01$, ${ }^{* * *} P \leq 0.001$; NS, non-significant; SOV, source of variation; CV, coefficient of variation.

more available under limited water environment (Zhao et al., 2007).

\section{CONCLUSION}

To the best of our knowledge, the present study is one of the few reports on the effects of exogenous Se supply on maize fodder yield and quality under water deficit conditions. Positive effects of Se supplementation on fodder yield and quality were found to be associated with Se-mediated regulation of physiological and biochemical processes such as maintenance of turgor due to accumulation of osmolytes like TFA, increased chlorophyll and carotenoid contents and activation of antioxidant machinery

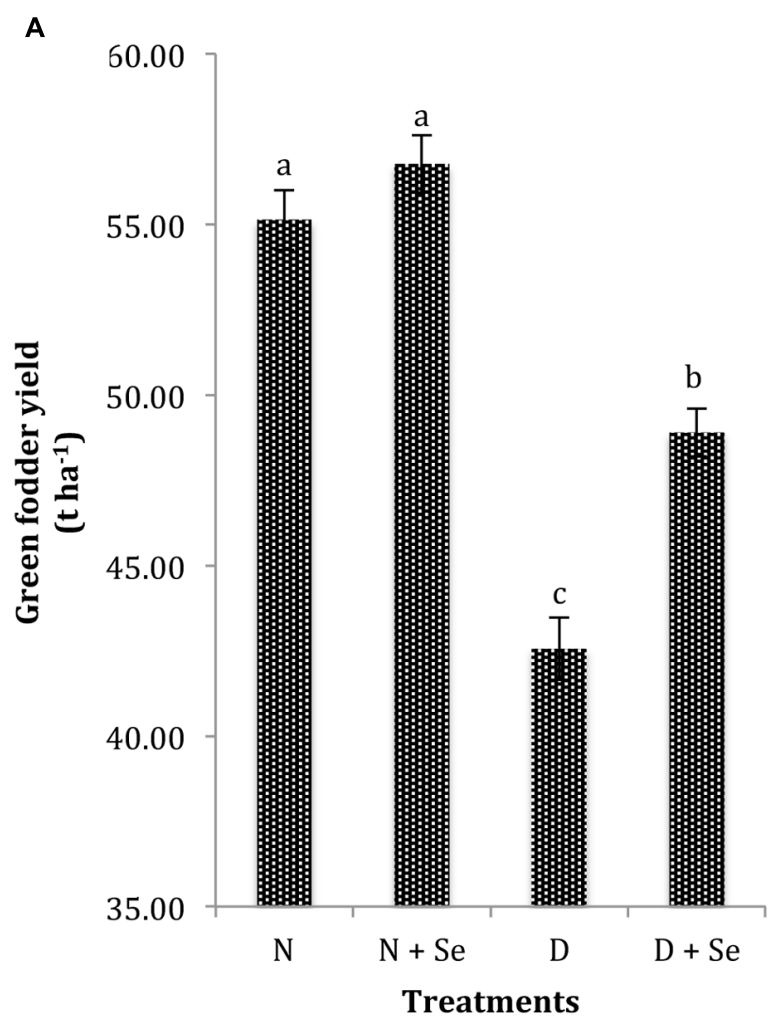

B

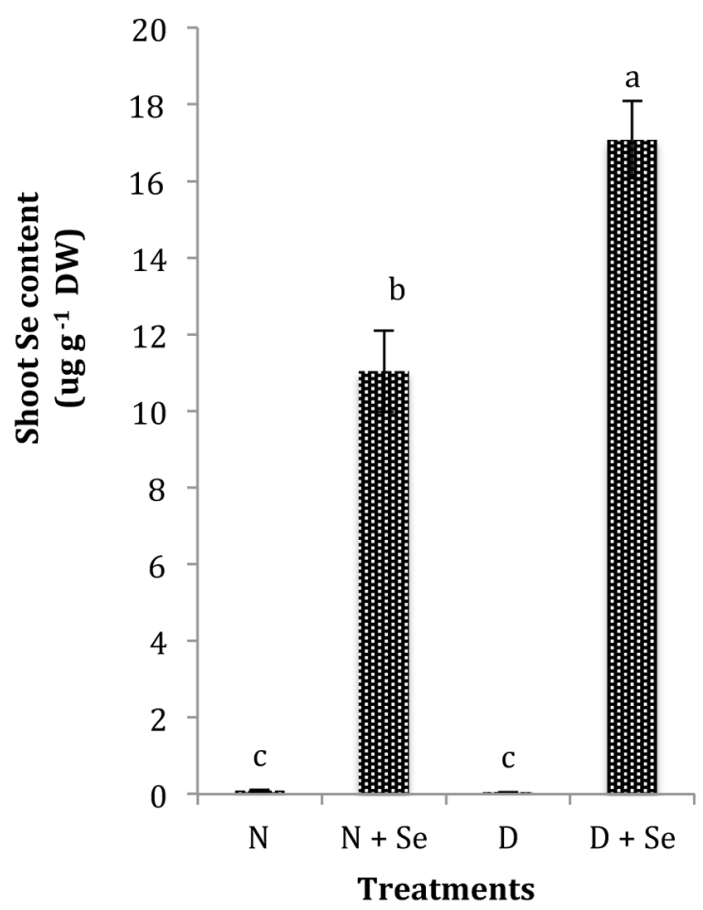

FIGURE 5 | Effect of Se foliar spray on (A) green fodder yield (GFY) and (B) shoot Se content of Zea mays exposed to drought stress. Values represent mean \pm SE. Different letters represent significant differences at $P \leq 0.05$, after applying post hoc Tukey's test. 
in water stressed maize plants. Moreover, foliar Se supply also increased Se content in shoot, which may be exploited as a viable and effective approach to increase Se concentration in fodders for the development of balanced livestock ration particularly in areas with low Se levels in soils.

\section{AUTHOR CONTRIBUTIONS}

FN, MN, and MT conceived and designed the study, FN wrote the manuscript, MA and RS provided reagents and analyzed results, $\mathrm{BZ}$ and MS performed the analytical works, MA managed the treatments application.

\section{REFERENCES}

Abbas, S. M. (2012). Effects of low temperature and selenium application on growth and the physiological changes in sorghum seedlings. J. Stress Physiol. Biochem. $8,268-286$.

Abd-Allah, E. F., Alqarawi, A. A., and Abeer, H. (2016). Mitigation of cadmium induced stress in tomato (Solanum lycopersicum L.) by selenium. Pak. J. Bot. 48, 953-961.

Abraha, A. B., Truter, W. F., Annandale, J. G., and Fessehazion, M. K. (2015). Forage yield and quality response of annual ryegrass (Lolium multiflorum) to different water and nitrogen levels. Afri. J. Range Forage Sci. 32, 125-131. doi: $10.2989 / 10220119.2015 .1056228$

Abul-Soud, M. A., and Abd-Elrahman, S. H. (2016). Foliar selenium application to improve the tolerance of eggplant grown under salt stress conditions. Int. J. Plant Soil Sci. 9, 1-10. doi: 10.9734/IJPSS/2016/19992

Ahmad, R., Waraich, E. A., Nawaz, F., Ashraf, M. Y., and Khalid, M. (2016). Selenium (Se) improves drought tolerance in crop plants-a myth or fact? J. Sci. Food Agri. 96, 372-380. doi: 10.1002/jsfa.7231

Akbulut, M., and Cakir, S. (2010). The effects of Se phytotoxicity on the antioxidant systems of leaf tissues in barley (Hordeum vulgare L.) seedlings. Plant physiol. Biochem. 48, 160-166. doi: 10.1016/j.plaphy.2009.11.001

Akladious, S. A. (2012). Influence of different soaking times with selenium on growth, metabolic activities of wheat seedlings under low temperature stress. Afri. J. Biotech. 11, 14792-14804.

AOAC (1984). Methods of Analysis, 14th Edn. Washington, DC: Association of Official Analytical Chemists.

Arnon, D. I. (1949). Copper enzymes in isolated chloroplasts. Polyphenoloxidase in Beta vulgaris. Plant physiol. 24, 1-15.

Balal, R. M., Shahid, M. A., Javaid, M. M., Iqbal, Z., Anjum, M. A., GarciaSanchez, F., et al. (2016). The role of selenium in amelioration of heat-induced oxidative damage in cucumber under high temperature stress. Acta Physiol. Plantarum. 38, 1-14. doi: 10.1007/s11738-016-2174-y

Bibi, A., Sadaqat, H. A., Tahir, M. H. N., and Akram, H. M. (2012). Screening of sorghum (Sorghum bicolor varMoench) for drought tolerance at seedling stage in polyethylene glycol. J. Anim. Plant Sci 22, 671-678.

Broadley, M. R., Alcock, J., Alford, J., Cartwright, P., Foot, I., Fairweather-Tait, S. J., et al. (2010). Selenium biofortification of high-yielding winter wheat (Triticum aestivum L.) by liquid or granular Se fertilisation. Plant Soil 332, 5-18. doi: 10.1007/s11104-009-0234-4

Cakmak, I. (1994). Activity of ascorbate-dependent H2O2-scavenging enzymes and leaf chlorosis are enhanced in magnesium- and potassium-deficient leaves, but not in phosphorus-deficient leaves. J. Exp. Bot. 45, 1259-1266. doi: 10.1093/jxb/45.9.1259

Cartes, P., Gianfreda, L., and Mora, M. L. (2005). Uptake of selenium and its antioxidant activity in ryegrass when applied as selenate and selenite forms. Plant Soil. 276, 359-367. doi: 10.1007/s11104-005-5691-9

Cartes, P., Jara, A. A., Pinilla, L., Rosas, A., and Mora, M. L. (2010). Selenium improves the antioxidant ability against aluminium-induced oxidative stress in ryegrass roots. Ann. Appl. Bio. 156, 297-307. doi: 10.1111/j.17447348.2010.00387.x

\section{FUNDING}

We are highly grateful to Higher Education Commission (HEC) of Pakistan for providing financial support to this study under Startup Research Grant (SRGP) No. 21753/SRGP/R\&D/HEC/2014.

\section{ACKNOWLEDGMENT}

We are also thankful to Mr. Ghulam Farid, Research Assistant, Nuclear Institute for Agriculture and Biology, Faisalabad, Pakistan for providing assistance in analytical work.

Chilimba, A. D., Young, S. D., Black, C. R., Meacham, M. C., Lammel, J., and Broadley, M. R. (2012). Agronomic biofortification of maize with selenium (Se) in Malawi. Field Crops. Res. 125, 118-128. doi: 10.1016/j.fcr.2011.08.014

Chu, J., Yao, X., and Zhang, Z. (2010). Responses of wheat seedlings to exogenous selenium supply under cold stress. Bio. Trace Elem. Res. 136, 355-363. doi: 10.1007/s12011-009-8542-3

Clarke, J. M., and McCaig, T. N. (1982). Excised-leaf water retention capability as an indicator of drought resistance of Triticum genotypes. Can. J. Plant Sci. 62, 571-578. doi: 10.4141/cjps82-086

Davies, B. (1976). "Carotenoids," in Chemistry and Biochemistry of Plant Pigments, ed. T. W. Goodwin (London: Academic Press), 38-165.

Dhillon, K. S., and Dhillon, S. K. (2003). Quality of underground water and its contribution towards selenium enrichment of the soil-plant system for a seleniferous region of northwest. Ind. J. Hydrol. 272, 120-130. doi: 10.1016/S0022-1694(02)00259-7

Dixit, V., Pandey, V., and Shyam, R. (2001). Differential antioxidative response to cadmium in roots and leaves of pea. J. Exp. Bot. 52, 1101-1109. doi: $10.1093 /$ jexbot/52.358.1101

Djanaguiraman, M., Devi, D. A. K., Shanker, A., Sheeba, A., and Bangarusamy, U. (2004). Impact of selenium spray on monocarpic senescence of soybean (Glycine max L.). Food Agri. Environ. 2, 44-47.

Djanaguiraman, M., Devi, D. D., Shanker, A. K., Sheeba, J. A., and Bangarusamy, U. (2005). Selenium-an antioxidative protectant in soybean during senescence. Plant Soil 272, 77-86. doi: 10.1007/s11104-004-4039-1

Dong, J. Z., Wang, Y., Wang, S. H., Yin, L. P., Xu, G. J., Zheng, C., et al. (2013). Selenium increases chlorogenic acid, chlorophyll and carotenoids of Lycium chinense leaves. J. Sci. Food Agri. 93, 310-315. doi: 10.1002/jsfa.5758

Drahoňovský, J., Száková, J., Mestek, O., Tremlová, J., Kaňa, A., Najmanová, J., et al. (2016). Selenium uptake, transformation and inter-element interactions by selected wildlife plant species after foliar selenate application. Environ. Exp. Bot. 125, 12-19. doi: 10.1016/j.envexpbot.2016.01.006

Ducsay, L., Ložek, O., and Varga, L. (2009). Effect of selenium foliar application on its content in spring barley. Agrochémia. 12, 3-6.

Filek, M., Zembala, M., Hartikainen, H., Miszalski, Z., Korna’s, A., WieteckaPosłuszny, R., et al. (2009). Changes in wheat plastid membrane properties induced by cadmium and selenium in presence/absence of 2 , 4-dichlorophenoxyacetic acid. Plant Cell Tiss. Org. Cult. 96, 19-28. doi: $10.1007 / \mathrm{s} 11240-008-9455-0$

Fordyce, F. (2005). "Selenium deficiency and toxicity in the environment," in Essentials of Medical Geology, Impacts of the Natural Environment on Public Health, eds O. Selinus, B. Alloway, J. A. Centeno, R. B. Finkelman, R. Fuge, U. Lindh, et al. (Boston, MA: Elsevier Academic Press), 373-415.

Fordyce, F. M. (2013). "Selenium deficiency and toxicity in the environment," in Essentials of Medical Geology, ed. O. Selinus (Berlin: Springer), 375-416.

Germ, M., Kreft, I., Stibilj, V., and Urbanc-Berčič, O. (2007). Combined effects of selenium and drought on photosynthesis and mitochondrial respiration in potato. Plant Physiol. Biochem. 45, 162-167. doi: 10.1016/j.plaphy.2007. 01.009

Giannopolitis, C. N., and Ries, S. K. (1997). Superoxide dismutase I. Occurrence in higher plants. Plant Physiol. 59, 309-314. 
Good, A. G., and Zaplachinski, S. T. (1994). The effects of drought stress on free amino acid accumulation and protein synthesis in Brassica napus. Physiol. Plant 90, 9-14. doi: 10.1034/j.1399-3054.1994.900102.x

Habibi, G. (2013). Effect of drought stress and selenium spraying on photosynthesis and antioxidant activity of spring barley. Acta Agric. Slov. 101, 31-39.

Hajiboland, R., and Keivanfar, N. (2012). Selenium supplementation stimulates vegetative and reproductive growth in canola (Brassica napus L.) plants. Acta Agric. Slov. 99, 13-19. doi: 10.2478/v10014-012-0002-7

Hajiboland, R., Sadeghzadeh, N., and Sadeghzadeh, B. (2014). Effect of Se application on photosynthesis, osmolytes and water relations in two durum wheat (Triticum durum L.) genotypes under drought stress. Acta Agric. Slov. 103, 167-179.

Hamilton, P. B., and Van Slyke, D. D. (1943). Amino acids determination with ninhydrin. J. Biol. Chem. 150, 231-233.

Hartikainen, H., Xue, T., and Piironen, V. (2000). Selenium as an anti-oxidant and pro-oxidant in ryegrass. Plant Soil 225, 193-200. doi: 10.1023/A:1026512921026

Hasanuzzaman, M., and Fujita, M. (2011). Selenium pretreatment up-regulates the antioxidant defense and methylglyoxal detoxification system and confers enhanced tolerance to drought stress in rapeseed seedlings. Biol. Trace Elem. Res. 143, 1758-1776. doi: 10.1007/s12011-011-8958-4

Hasanuzzaman, M., Hossain, M. A., and Fujita, M. (2012). Exogenous selenium pretreatment protects rapeseed seedlings from cadmium-induced oxidative stress by upregulating antioxidant defense and methylglyoxal detoxification systems. Biol. Trace Elem. Res. 149, 248-261. doi: 10.1007/s12011-012-9419-4

Hawrylak-Nowak, B. (2009). Beneficial effects of exogenous selenium in cucumber seedlings subjected to salt stress. Biol. Trace Elem. Res. 132, 259-269. doi: 10.1007/s12011-009-8402-1

Hawrylak-Nowak, B., Matraszek, R., and Szymańska, M. (2010). Selenium modifies the effect of short-term chilling stress on cucumber plants. Biol. Trace Elem. Res. 138, 307-315. doi: 10.1007/s12011-010-8613-5

Hefnawy, A. E. G., and Tórtora-Pérez, J. L. (2010). The importance of selenium and the effects of its deficiency in animal health. Small Rumin. Res. 89, 185-192. doi: 10.1016/j.smallrumres.2009.12.042

Hsu, S. Y., Hsu, Y. T., and Kao, C. H. (2003). The effect of polyethylene glycol on proline accumulation in rice leaves. Biol. Plant. 46, 73-78. doi: 10.1023/A:1024888217021

Hussain, R. A., Ahmad, R., Nawaz, F., Ashraf, M. Y., and Waraich, E. A. (2016). Foliar NK application mitigates drought effects in sunflower (Helianthus annuus L.). Acta Physiol. Plant. 38, 1-14. doi: 10.1007/s11738-0162104-Z

Jackson, M. L. (1962). Soil Chemical Analysis. London: Constable and company.

Kaldenhoff, R., Ribas-Carbo, M., Sans, J. F., Lovisolo, C., Heckwolf, M., and Uehlein, N. (2008). Aquaporins and plant water balance. Plant Cell Environ. 31, 658-666. doi: 10.1111/j.1365-3040.2008.01792.x

Khan, M. I. R., Nazir, F., Asgher, M., Per, T. S., and Khan, N. A. (2015). Selenium and sulfur influence ethylene formation and alleviate cadmium-induced oxidative stress by improving proline and glutathione production in wheat. J. Plant Physiol. 173, 9-18. doi: 10.1016/j.jplph.2014 .09 .011

Khanal, D. R., and Knight, A. P. (2010). Selenium: its role in livestock health and productivity. J. Agric. Environ. 11, 101-106. doi: 10.1007/s12011-012-9583-6

Khayatnezhad, M., Gholamin, R., Jamaati-e-Somarin, S., and Zabihi-eMahmoodabad, R. (2011). The leaf chlorophyll content and stress resistance relationship considering in Corn cultivars (Zea mays L.). Adv. Environ. Biol. 5, 118-122.

Krishnaiah, L., Suresh Kumar, K., Suvardhan, K., and Chiranjeevi, P. (2003). "Simple spectrophotometric determination of traces of selenium in environmental samples," in Proceedings of the Third International Conference on Environment and Health, Chennai, India, 15-17 December, 2003, eds J. Martin, V. Bunch, Madha Suresh and T. VasanthaKumaran (Chennai: University of Madras and Faculty of Environmental Studies), 217-225.

Küchenmeister, K., Küchenmeister, F., Kayser, M., Wrage-Mönnig, N., and Isselstein, J. (2013). Influence of drought stress on nutritive value of perennial forage legumes. Int. J. Plant Prod. 7, 693-710.

Kumar, M., Bijo, A. J., Baghel, R. S., Reddy, C. R. K., and Jha, B. (2012). Selenium and Sperminealleviates cadmium induced toxicity in the red seaweed Gracilariadura by regulating antioxidant system and DNA methylation. Plant Physiol. Biochem. 51, 129-138. doi: 10.1016/j.plaphy.2011.10.016
Kuznetsov, V. V., Kholodova, V. P., Kuznetsov, V. I. V., and Yagodin, B. A. (2003). Selenium regulates the water status of plants exposed to drought. Dokl. Biol. Sci. 390, 266-268. doi: 10.1023/A:1024426104894

Leccia, M. T., Richard, M. J., Bean, J. C., Faure, H., Monjo, A. M., Cadet, J., et al. (1993). Protective effect of selenium and zinc on uv-a damage in human skin fibroblasts. Photochem. photobiol 58, 548-553. doi: 10.1111/j.17511097.1993.tb04930.x

Li, M. Q., Hasan, M., Li, C. X., Ahammed, G. J., Xia, X. J., Shi, K., et al. (2016). Melatonin mediates selenium-induced tolerance to cadmium stress in tomato plants. J. Pineal Res. 61, 291-302. doi: 10.1111/jpi.12346

Lonbani, M., and Arzani, A. (2011). Morpho-physiological traits associated with terminal drought-stress tolerance in triticale and wheat. Agron. Res. 9, 315-329.

Malik, J. A., Goel, S., Kaur, N., Sharma, S., Singh, I., and Nayyar, H. (2012). Selenium antagonises the toxic effects of arsenic on mungbean (Phaseolus aureus Roxb.) plants by restricting its uptake and enhancing the antioxidative and detoxification mechanisms. Environ. Exp. Bot. 77, 242-248. doi: 10.1016/j.envexpbot.2011.12.001

Marschner, H. (1995). Mineral Nutrition of Higher Plants. London: Academic Press, 889.

Mayak, S., Tirosh, T., and Glick, B. R. (2004). Plant growth-promoting bacteria that confer resistance in tomato and pepper plants to salt stress. Plant Physiol. Biochem. 42, 565-572. doi: 10.1016/j.plaphy.2004.05.009

Mittler, R., Vanderauwera, S., Gollery, M., and Van Breusegem, F. (2004). Reactive oxygen gene network of plants. Trends Plant Sci. 9, 490-498. doi: 10.1016/j.tplants.2004.08.009

Nawaz, F., Ahmad, R., Ashraf, M. Y., Waraich, E. A., and Khan, S. Z. (2015a). Effect of selenium foliar spray on physiological and biochemical processes and chemical constituents of wheat under drought stress. Ecotoxicol. Environ. Saf. 113, 191-200. doi: 10.1016/j.ecoenv.2014.12.003

Nawaz, F., Ashraf, M. Y., Ahmad, R., and Waraich, E. A. (2013). Selenium (Se) seed priming induced growth and biochemical changes in wheat under water deficit conditions. Biol. Trace Elem. Res. 151, 284-293. doi: 10.1007/s12011-0129556-9

Nawaz, F., Ashraf, M. Y., Ahmad, R., Waraich, E. A., Shabbir, R. N., and Bukhari, M. A. (2015b). Supplemental selenium improves wheat grain yield and quality through alterations in biochemical processes under normal and water deficit conditions. Food Chem. 175, 350-357. doi: 10.1016/j.foodchem.2014. 11.147

Nowak, J., Kaklewski, K., and Ligocki, M. (2004). Influence of selenium on oxidoreductive enzymes activity in soil and plants. Soil Biol. Biochem. 36, 1553-1558. doi: 10.1016/j.jplph.2007.04.010

Padmaja, K., Somasekharaiah, B. V., and Prasad, A. R. (1995). Inhibition of chlorophyll synthesis by selenium: involvement of lipoxygenase mediated lipid peroxidation and antioxidant enzymes. Photosynthetica 31, 1-7.

Pazurkiewicz-Kocot, K., Kita, A., and Pietruszka, M. (2008). Effect of selenium on magnesium, iron, manganese, copper, and zinc accumulation in corn treated by indole-3-acetic acid. Comm. Soil Sci. Plant Anal. 39, 2303-2318. doi: $10.1080 / 00103620802292343$

Peng, Q., and Zhou, Q. (2009). Antioxidant capacity of flavonoid in soybean seedlings under the joint actions of rare earth element la(iii) and ultraviolet-B stress. Biol. Trace Elem. Res. 127, 69-80. doi: 10.1007/s12011-008-8218-4

Pii, Y., Cesco, S., and Mimmo, T. (2015). Shoot ionome to predict the synergism and antagonism between nutrients as affected by substrate and physiological status. Plant Physiol. Biochem. 94, 48-56. doi: 10.1016/j.plaphy.2015. 05.002

Qiang-yun, S., Turakainen, M., Seppanen, M., and Makela, P. (2008). Effects of selenium on maize ovary development at pollination stage under drought stress. Agric. Sci. China. 7, 1298-1307. doi: 10.1016/S1671-2927(08) 60178-9

Ramos, S. J., Faquin, V., Guilherme, L. R. G., Castro, E. M., Ávila, F. W., Carvalho, G. S., et al. (2010). Selenium biofortification and antioxidant activity in lettuce plants fed with selenate and selenite. Plant Soil Environ. 56, 584-588.

Raza, M. A. S., Saleem, M. F., Khan, I. H., Jamil, M., Ijaz, M., and Khan, M. A. (2012). Evaluating the drought stress tolerance efficiency of wheat (Triticum aestivum L.) cultivars. Russian J. Agric. Socio-Economic Sci. 12, 41-46.

Sajedi, N., Madani, H., and Naderi, A. (2011). Effect of microelements and selenium on superoxide dismutase enzyme, malondialdehyde activity and grain yield maize (Zea mays L.) under drought stress. Not. Bot. Horti. Agrobo. 39, 153-159. 
Seppänen, M., Turakainen, M., and Hartikainen, H. (2003). Selenium effects on oxidative stress in potato. Plant Sci. 165, 311-319. doi: 10.1016/S01689452(03)00085-2

Shabbir, R. N., Waraich, E. A., Ali, H., Nawaz, F., Ashraf, M. Y., Ahmad, R., et al. (2016). Supplemental exogenous NPK application alters biochemical processes to improve yield and drought tolerance in wheat (Triticum aestivum L.). Environ. Sci. Pollut. Res. 23, 2651-2662. doi: 10.1007/s11356-015-5452-0

Staniak, M., and Kocoń, A. (2015). Forage grasses under drought stress in conditions of Poland. Acta Physiol. Plantar. 37, 1-10. doi: 10.1007/s11738-0151864-1

Terry, N., Zayed, A. M., de Souza, M. P., and Tarun, A. S. (2000). Selenium in Higher Plants. Annu. Rev. Plant Physiol. Plant Mol. Biol. 51, 401-432. doi: 10.1146/annurev.arplant.51.1.401

Turakainen, M., Hartikainen, H., and Seppänen, M. M. (2004). Effects of selenium treatments on potato (Solanum tuberosum L.) growth and concentrations of soluble sugars and starch. J. Agric. Food Chem. 25, 5378-5382. doi: $10.1021 /$ jf040077x

Wang, C. Q. (2011). Water-stress mitigation by selenium in Trifoliumrepens L. J. Plant Nutr. Soil Sci. 174, 276-282. doi: 10.1002/jpln.200900011

Wang, Y. D., Wang, X., and Wong, Y. S. (2013). Generation of seleniumenriched rice with enhanced grain yield, selenium content and bioavailability through fertilisation with selenite. Food Chem. 141, 2385-2393. doi: 10.1016/j.foodchem.2013.05.095

White, P. J. (2016). Selenium accumulation by plants. Ann. Bot. 117, 217-235. doi: $10.1093 / \mathrm{aob} / \mathrm{mcv} 180$

Xu, H., Biswas, D. K., Li, W. D., Chen, S. B., Zhang, S. B., Jiang, G. M., et al. (2007). Photosynthesis and yield responses of ozone-polluted winter wheat to drought. Photosynthetica 45, 582-588. doi: 10.1007/s11099-007-0100-7

$\mathrm{Xu}$, J., and Hu, Q. (2004). Effect of foliar application of selenium on the antioxidant activity of aqueous and ethanolic extracts of selenium-enriched rice. J. Agric. Food Chem. 52, 1759-1763. doi: 10.1021/jf0349836

Yao, X., Chu, J., and Wang, G. (2009). Effects of selenium on wheat seedlings under drought stress. Biol. Trace Elem. Res. 130, 283-290. doi: 10.1007/s12011-0098328-7

Yao, X., Jianzhou, C., Xueli, H., Binbin, L., Jingmin, L., and Zhaowei, Y. (2013). Effects of selenium on agronomical characters of winter wheat exposed to enhanced ultraviolet-B. Ecotoxicol. Environ. Saf. 92, 320-326. doi: 10.1016/j.ecoenv.2013.03.024

Yao, Y., Pei, F., and Kang, P. (2011). Selenium, iodine, and the relation with Kashin-Beck disease. Nutrition 27, 1095-1100. doi: 10.1016/j.nut.2011.03.002

Zahedi, H., Rad, A. H. S., and Moghadam, H. R. T. (2013). Effect of zeolite and selenium foliar application on growth, production and some physiological attributes of three canola (Brassica napus L.) cultivars subjected to drought stress. Rev. Cientifica UDO Agric. 12, 136-143.

Žáková, N. (2014). Selenium Content in Blood of Sport and Recreational Horses. Diploma thesis, Czech University of Life Sciences, Prague.

Zhang, L., Li, Q., Yang, X., and Xia, Z. (2012). Effects of sodium selenite and germination on the sprouting of chickpeas (Cicer arietinum L.) and its content of selenium, for- mononetin and biochanin A in the sprouts. Biol. Trace Elem. Res. 146, 376-380. doi: 10.1007/s12011-011-9261-0

Zhao, F. J., Lopez-Bellido, F. J., Gray, C. W., Whalley, W. R., Clark, L. J., and McGrath, S. P. (2007). Effects of soil compaction and irrigation on the concentrations of selenium and arsenic in wheat grains. Sci. Total Environ. 372, 433-439. doi: 10.1016/j.scitotenv.2006.09.028

Zhao, Y., Wu, P., Wang, Y., and Feng, H. (2013). Different approaches for selenium biofortification of pear-jujube (Zizyphus jujuba M. cv. Lizao) and associated effects on fruit quality. J. Food Agric. Environ. 11, 529-534.

Živčák, M., Repková, J., Olšovská, K., and Brestič, M. (2009). Osmotic adjustment in winter wheat varieties and its importance as a mechanism of drought tolerance. Cereal Res. Commun. 37, 569-572.

Conflict of Interest Statement: The authors declare that the research was conducted in the absence of any commercial or financial relationships that could be construed as a potential conflict of interest.

Copyright (c) 2016 Nawaz, Naeem, Ashraf, Tahir, Zulfiqar, Salahuddin, Shabbir and Aslam. This is an open-access article distributed under the terms of the Creative Commons Attribution License (CC BY). The use, distribution or reproduction in other forums is permitted, provided the original author(s) or licensor are credited and that the original publication in this journal is cited, in accordance with accepted academic practice. No use, distribution or reproduction is permitted which does not comply with these terms. 